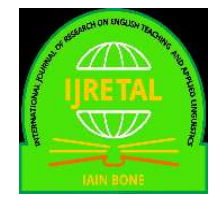

IJRETAL

International Journal of Research on English Teaching and Applied Linguistics

Vol. 1, No.1, June 2020

\title{
THE STUDENTS' EXTROVERT AND INTROVERT PERSONALITY TOWARD SPEAKING PERFORMANCE
}

\author{
Novita Paradilla ${ }^{1}$, Muhammad Zuhri Dj. ${ }^{* 2}$, Uswatun Hasanah ${ }^{3}$ \\ 1,2,3 Department of English Education, Institut Agama Islam Negeri Bone, Indonesia \\ Corresponding Author Email: zuhristaindije@gmail.com
}

\begin{abstract}
This research aims to analyze the influence of personality in speaking performance. The focus was an analysis of the influence of the extrovert and introvert personality of the student toward speaking performance. This research employed a descriptive qualitative research method with a case study approach. The data was collected through questionnaires, interviews, and speaking tests. The subject of this research was students at MA Baytul Mukarromah Welalange. There were 10 consisted of 5 extrovert and 5 introvert students that had been divided by using the Eysenck Personality Questionnaire to acquire the data needed. The data analysis was employed based on the procedure of data analysis suggested by Miles and Huberman that consisted of step reduction, display, and verification data. The result of this data described that there was no influence between extrovert and introvert personality toward speaking performance, but it is influenced by different levels of knowledge and frequent participation or well preparation. It showed that personality types are not a determiner factor for the success of Speaking Performance, it can be suggested that students with different personality types may employ different kinds of strategies for learning. Consequently, whether extrovert or introvert as long as the student had enough knowledge about the topic and also was supported by frequent participation or well preparation, the speaking performance would be better.

Keywords: Influence; Extrovert and Introvert Personality; Speaking Performance
\end{abstract}

\section{INTRODUCTION}

Speaking is to say words orally, to communicate as by talking, to make a request, and to make a speech. (Ahmadi, 2017). ). Through speaking, people can express ideas and maintain social relationships even convey and receive information that is happening in this life. (Nazlia, May 2015). Without good speaking skills, communication will not be effective and it can cause misunderstanding one another. There are some speaking problems that teachers can come across in getting students to talk in the classroom. These are inhibition, lack of topical knowledge, low or uneven participation. (Ur, 2012). Therefore, having a good skill in speaking is needed to get a good speaking performance. Speaking performance is oral communication that requires the ability to use the language appropriately in social interaction not only verbal communication but also uses gesture, body language, and expression. (Misti, 2018). However, the speaking performance of every person will be different.

Related to this, there are several factors influence speaking performance such as age, environment, social-cultural factors, aural medium, and personality. Among the factors which have much the student is personality (Samand, 2019). Personality is everything characteristics which can affect characteristic especially the way of thinking, feeling even behaving of someone. Personality is the supreme realization of the innate idiosyncrasy of a living being and according to the attitude of individuals, there are extrovert and introvert groups of students. (Schustack, 2008).

Commonly, Extrovert is a person who is more concerned with what is happening around him than in his own emotions and thoughts. (Suliman, February 2015). Typical extroverts are generally depicted as sociable, like parties, have some friends, need person to 
IJRETAL

International Journal of Research on English Teaching and Applied Linguistics, Vol. 1, No.1, June 2020

talk to, and do not like studying by himself. (Yan Chen, 2015). This means that Extrovert are sociable, easy-going, prefer outdoor activities, or participating in various social.

Contrary to extrovert, based on reality in around environment introvert personality is thinker, less social, seldom speak and ashamed person who involve themselves minimally in social activities. Introverts prefer to spend time in small groups, or one-on-one, and usually like to get to know new people more slowly, but actually they are just social in different ways. It shows that Introvert are personal, closed and quiet person. By these two kinds of different personalities, it will also enable the influence especially toward student speaking performance where there are some students do it quite good, but not with others. Students keep quiet is not because they are not able to speak English, but they are worried will do mistake or they feel anxiety. Some students who have a good self confidence do not think too much about will do mistake. Contrary, some students who are passive will speak confidently if the answer is believed will be right. One of the intuitively appealing hypotheses is extrovert learn more rapidly than introvert learner. (Schwartz, effective Character Education, 2007). It is because introvert students prefer to study alone rather. (Souzandehfar, January 10th 2017) than extrovert learners will be easier to make contact with other users of the second language and therefore will obtain more input.(Schwartz, effective Character Education, 2007). The other theory is about an extrovert is a type of person who is dare takes risks and does not afraid of making mistakes. (Ali Sukru Ozbay, 2017).

There is also a different learning style such as introvert students prefer to study alone while extroverts prefer to participate and study in a group (Clarry Sada, 2015). Based on the explanation above, the extrovert personality can be better in speaking because get more input is quite easy for students. On the other hand, the introvert personality may also have the possibility to be better in speaking because introvert will think deeper before trying to speak a lot so the performance is better inaccuracy.

The researcher chooses both of these personalities between extrovert and introvert, it is caused by the researcher has a deep curiosity to do analysis which is aimed to know the influence between extrovert and introvert toward speaking performance. Based on the reason above, the researcher is interested in conducting research entitled: "The Students' Extrovert and Introvert Personality toward Speaking Performance".

Speaking is an interactive process of constructing meaning that involves producing and receiving information. (Yuen Chee Keong, December 2015,). ,). It consists of producing systematic verbal utterances to convey meaning. In speaking, people must have the ability to use the words with the correct pronunciation, to design the correct grammar for utterances, and to choose the diction or choice of words. Therefore, having a good performance in speaking skill is the single most important aspect of learning a second or foreign language (Nunan, 2003)

Personality is the organized, developing system within the individual that represents the collective action of that individual's major psychological subsystems. (Agras, 21 December 2017). It means an individual's characteristic patterns of thought, emotion, and behavior, together with the psychological mechanisms hidden or not behind those patterns or the pattern of consistent behavior and quality in a person. Eysenck stated that personality is the sum-total of actual or potential behavior patterns of the organism as determined by heredity and environment (Sharma, 2013).

Extroverts are more influenced by their surroundings than by their inner world (Chen, May 2015). Typical extroverts are generally depicted as sociable, like parties, have some friends, need a person to talk to, and do not like studying by himself. (Suryabrata, 2008). This means that Extrovert are sociable, easy-going, prefer outdoor activities, or participating in various social. An introvert is a preference to focus on the world inside the self. (Suryabrata, 2008).

The Students' Extrovert and Introvert Personality toward Speaking Performance

Novita Paradillah, Muhammad Zuhri Dj., \& Uswatun Hasanah, Page 38-50 
IJRETAL

International Journal of Research on English Teaching and Applied Linguistics, Vol. 1, No.1, June 2020

An introvert is a preference to focus on the world inside the self (L.R. Gay, 2012). Introverts prefer to spend time in small groups, or one-on-one, and usually like to get to know new people more slowly, but they are just social in different ways. (al, March 2016).

Related to this, the objective of the research is The Students' Extrovert and Introvert Personality toward Speaking Performance.

\section{RESEARCH METHOD}

The method is of this research applied descriptive qualitative with a case study approach. Qualitative research is the collection and analysis, interpretation of comprehensive narrative, and visual data to gain insight into a particular phenomenon of interest. A case study is a qualitative research approach to researching a unit of study or bounded system (e.g., an individual teacher, a classroom, or a school can be a case).

The subject of this research took 10 students at the Eleventh grade of MA Baytul Mukarromah Welalange, where there are five extrovert and five introvert students by using questionnaire to acquire data needed. The questionnaire was used to find out and clarification the student belonged to extrovert and introvert. (Dyah Sri Wulandari, 2017) This questionnaire is taken from the source of the Eysenck Personality Questionnaire (EPQ).

The instrument was a methodological research tool used in research to collect the data. The researcher needed some instruments. The instruments are questionnaires, interviews, and speaking tests.

This procedure of collecting data of the research followed the procedure as follows:

\section{a. Questionnaire}

The instrument of this research used questionnaires (just for determining the student's personality between extrovert and introvert). The researcher met directly some students then gave 23 numbers of the questionnaire but it is modified with the requirement which is suitable for the researcher's needs and also developed base on personality theory.

b. Interview

The researcher has to meet directly and makes a good conversation with the students one by one. Then, the researcher asked the students' experience in speaking and about their habits and obstacle while speaking. In doing the interview, the researcher also recorded them at that time.

c. Speaking test

The researcher asked the student to tell their experience one by one in front of their friends. The researcher focused and assessed the students' speaking performance as a data to analyze the influence of extrovert and introvert personality in speaking performance of the student based on the rubric that proposed by Sugiyono.

Table 1

"Speaking Performance Scoring Criteria"

\begin{tabular}{|c|c|c|c|c|c|}
\hline No & Criteria & Excellent & Very Good & Good & Poor \\
\hline 1. & $\begin{array}{l}\text { Self } \\
\text { Confidence }\end{array}$ & $\begin{array}{l}\text { The speaker } \\
\text { has very good } \\
\text { self confidence } \\
\text { and could } \\
\text { manage the } \\
\text { stage and the } \\
\text { audience well }\end{array}$ & $\begin{array}{l}\text { Looks a bit } \\
\text { nervous but } \\
\text { still could } \\
\text { manage the } \\
\text { stage and the } \\
\text { audience }\end{array}$ & $\begin{array}{l}\text { The speaker } \\
\text { has quite } \\
\text { good self } \\
\text { confidence }\end{array}$ & $\begin{array}{lr}\text { The } & \text { speaker } \\
\text { looks } & \text { very } \\
\text { nervous } & \end{array}$ \\
\hline
\end{tabular}

The Students' Extrovert and Introvert Personality toward Speaking Performance

Novita Paradillah, Muhammad Zuhri Dj., \& Uswatun Hasanah, Page 38-50 
IJRETAL

International Journal of Research on English Teaching and Applied Linguistics, Vol. 1, No.1, June 2020

\begin{tabular}{|c|c|c|c|c|c|}
\hline 2. & $\begin{array}{l}\text { Eye Contact } \\
\text { \& Gesture }\end{array}$ & $\begin{array}{l}\text { Stands up } \\
\text { straight, have a } \\
\text { good gesture } \\
\text { and establish } \\
\text { eye contact to } \\
\text { everyone in the } \\
\text { room during } \\
\text { performance }\end{array}$ & $\begin{array}{lr}\text { Stands } & \text { up } \\
\text { straight, have } \\
\text { a quite good } \\
\text { gesture and } \\
\text { establish eye } \\
\text { contact to } \\
\text { everyone. }\end{array}$ & \begin{tabular}{l}
\multicolumn{3}{l}{ Sometimes } \\
stands up \\
straight and \\
establish eye \\
contact
\end{tabular} & $\begin{array}{l}\text { Slouches and or } \\
\text { does not look at } \\
\text { people during } \\
\text { the performance }\end{array}$ \\
\hline 3. & Voice & $\begin{array}{l}\text { Speaks clearly, } \\
\text { distinctly and } \\
\text { have a quite } \\
\text { good intonation }\end{array}$ & $\begin{array}{l}\text { Speaks } \\
\text { clearly and } \\
\text { have a quite } \\
\text { good } \\
\text { intonation }\end{array}$ & $\begin{array}{l}\text { Sometimes } \\
\text { mumbles but } \\
\text { cannot be } \\
\text { understood }\end{array}$ & $\begin{array}{l}\text { Often mumbles } \\
\text { or cannot be } \\
\text { understood }\end{array}$ \\
\hline 4. & Pronunciation & $\begin{array}{l}\text { There is no } \\
\text { mispronounce. }\end{array}$ & $\begin{array}{l}\text { There are } \\
\text { mispronounce } \\
\mathrm{s} \text { no more } \\
\text { than two } \\
\text { words. }\end{array}$ & $\begin{array}{l}\text { There are } \\
\text { mispronounc } \\
\text { es three until } \\
\text { five words }\end{array}$ & $\begin{array}{l}\text { There are a lot } \\
\text { of } \\
\text { mispronounces }\end{array}$ \\
\hline 5. & Fluency & $\begin{array}{lr}\text { The } & \text { speaker } \\
\text { speaks } & \text { very } \\
\text { fluent } & \text { in } \\
\text { English like a } \\
\text { native. }\end{array}$ & $\begin{array}{l}\text { There are few } \\
\text { hesitation } \\
\text { during } \\
\text { speaking. }\end{array}$ & $\begin{array}{l}\text { There are } \\
\text { some } \\
\text { hesitation } \\
\text { during } \\
\text { speaking. }\end{array}$ & $\begin{array}{l}\text { The speaker } \\
\text { does not speak } \\
\text { fluently English. } \\
\text { There are a lot } \\
\text { of hesitations } \\
\text { during speaking. }\end{array}$ \\
\hline
\end{tabular}

The rubric above is used to know the student's speaking performance which each criteria has their level. The student's criteria of speaking test above that have been converted as excellent, very good, good, poor, and very poor want to be described as the result of this test. Hence, the students speaking performance is a description form as a requirement of qualitative research.

The qualitative data analysis suits this research is from Miles and Huberman. The approach was familiarly called 'transcendental realism' and the main components of their analysis are data reduction, data display, and verification data (Punch, (Singapore: SAGE, 2009)). The explanation of the main components is explained as follows:

a. Data reduction

Data reduction occurs continually throughout the analysis. It is part of the analysis. This stage, the researcher edits and reduces the result of the student's speaking performance. Then, the researcher will assess it and analyze the influence of personality in student speaking performance.

b. Data display

Data display is a stage to display the data. In this stage, the researcher collects the data either by using tables, graphs, or diagrams. The data is obtained from the results of data reduction.

c. Data verification 
IJRETAL

International Journal of Research on English Teaching and Applied Linguistics, Vol. 1, No.1, June 2020

The reasons for reducing and displaying data are to assist in drawing conclusions. The results of editing, coding and classification of students' errors without loss of information and displaying all the data that the researcher found from analyzing the students; writing. In the data verification, the researcher will conclude and verify the truth of the data that has been obtained (Punch, (Singapore: SAGE, 2009)

\section{FINDINGS AND DISCUSSION}

This chapter consists of two sections. The first section deals with data analysis through questionnaires, interviews, and speaking tests to analyze the influence of Extrovert and Introvert in Speaking Performance. The second section deals with the discussion.

\section{The result of questionnaire}

The questionnaire was taken from the Eysenck Personality Questionnaire (EPQ) for determining the student personality between extrovert and introvert. The group of student personality as the subject of the research based on the questionnaire, are:

Table 2. Initial Name

\begin{tabular}{|l|l|l|l|}
\hline NO & Initial Name & Male/Female & Personality \\
\hline 1 & EM & Female & Introvert \\
\hline 2 & WA & Female & Extrovert \\
\hline 3 & AMA & Male & Introvert \\
\hline 4 & J & Female & Extrovert \\
\hline 5 & AE & Female & Introvert \\
\hline 6 & IR & Female & Extrovert \\
\hline 7 & AMT & Male & Introvert \\
\hline 8 & MF & Female & Extrovert \\
\hline 9 & I & Female & Introvert \\
\hline 10 & MY & Female & Extrovert \\
\hline
\end{tabular}

Based on the data above, there were five extrovert and five introvert students that had been divided into personality group.

\section{The result of interview}

a. Extrovert

Extroverts are more influenced by their surroundings than by their inner world (Gary R. Vanden Bos and Jason M.Winkler, 2015). An extrovert is relatively more outgoing, gregarious, social, and openly expressive. Based on the explanation above, if it is related to a speaking problem such as; inhibition, lack of topical knowledge, and participation in speaking.

The Students' Extrovert and Introvert Personality toward Speaking Performance 
IJRETAL

International Journal of Research on English Teaching and Applied Linguistics, Vol. 1, No.1, June 2020

It shows that there are relations with extrovert students' view in the interview process that can be in the below:

1) Inhibition

Being worried about making mistakes, fearful of criticism, or losing face.

Researcher: What kinds of situations cause stress or anxiety for you?

MK: For me, it is okay to be seen by my friends, but when we are speaking then, our friends pay attention and realize our mistake, I barely would be more nervous.

2) Lack of Topical Knowledge

It is difficult for many students to respond when the teachers ask them to say something in a foreign language because they have little ideas about what to say, which vocabulary to use, or how to use the grammar correctly (Mai, 2010).it is showed by the extrovert students' interview below:

Researcher: Do you think the lack of topical knowledge is one of the difficulties for you? Why?

A: Hmm little bit ... em... maybe there will not be nervous if I have been mastered the material that will be performed.

3) Participation in Speaking

Another problem in speaking class is that participation is low or uneven. In a large group, each student will have very little talking time because only one participant can talk at a time so that the others can hear the student (Mai, 2010).

Researcher: Do you often participate in English learning? Why?

$\mathrm{J}$ : not bad, just not too concerned with the mistakes, because in speaking we do not pay attention to much about the grammar.

All these sentences showed the description of the extrovert student in speaking problems. Some of them did not feel afraid and nervous when speaking. It is supported by an extrovert characteristic which is usually fluent in speaking, free of feeling worried and not easy to get ashamed and awkward, love to work with others, and good at adapting with their surroundings (1958, Revised Edition).

\section{b. Introvert}

An introvert is a preference to focus on the world inside the self (Suryabrata, 2008). Introvert personality is a thinker, less social, and prefer to spend time in small groups, or oneon-one, and usually like to get to know new people more slowly, but actually, they are just social in different ways (al, Personality (Introvert, And Extrovert) and Professional Commitment Effect among B.Ed Teacher Educator Students, March 2016). Based on the theory above, if it is related to speaking problems had been discussed in the previous chapter. It showed that the students' statement was appropriate with it, the transcript of introvert students' view in the interview process could see in the below:

1) Inhibition

Being worried about making mistakes, fearful of criticism or losing face.

Researcher: What are the difficulties do you feel when speaking English?

AE: when we are asked to come forward, I feel afraid to be laughed by other friends.

\section{2) Lack of Topical Knowledge}

It is difficult for many students to respond when the teachers ask them to say something in a foreign language because they have little ideas about what to say, which vocabulary to use, or how to use the grammar correctly (Mai, Factors affecting student's Speaking Performance at Le Than Hien High Schoo). It is showed by the introvert students' interview below:

The Students' Extrovert and Introvert Personality toward Speaking Performance

Novita Paradillah, Muhammad Zuhri Dj., \& Uswatun Hasanah, Page 38-50 
IJRETAL

International Journal of Research on English Teaching and Applied Linguistics, Vol. 1, No.1, June 2020

Researcher: Do you think the lack of topical knowledge is one of the difficulties for you? Why?

AMA: it is quite inhibiting. If we come forward and forget the first vocabulary then we are going to forget all of them directly.

\section{3) Participation in Speaking}

Another problem in speaking class is that participation is low or uneven. In a large group, each student will have very little talking time because only one participant can talk at a time so that the others can hear the student.

Researcher: Do you often participate in English learning? Why?

EM: I often take apart, because I like it and want to understand more about English.

All these sentences showed the describing of the introvert student in the speaking problem. Some of them have anxiety about making mistakes. It relates by introvert characteristics that are thoughtful, careful, passive tend to be a focus and anxious. To find out more about the influence that exists from extrovert and introvert personality in speaking performance, there was the speaking test. The result will be present after analyzing the results of the speaking test based on the table below:

\section{The result of speaking test}

Table 3

"The result of students' speaking performance"

\begin{tabular}{|l|l|l|l|}
\hline No & Initial Name & Criteria & Analysis \\
\hline 1 & $\begin{array}{l}\text { EM } \\
\text { (Introvert) }\end{array}$ & $\begin{array}{l}\text { Very } \\
\text { good }\end{array}$ & $\begin{array}{l}\text {-Looks a bit nervous but still could manage the stage and } \\
\text { the audience } \\
\text {-Eye contact \& gesture stands up straight, have a quite good } \\
\text { gesture and establish eye contact to everyone. } \\
\text {-Voice is clear and have a quite good intonation } \\
\text {-There are mispronounces no more than two words. } \\
\text {-There are few hesitation during speaking }\end{array}$ \\
\hline 2 & $\begin{array}{l}\text { WA } \\
\text { (Extrovert) }\end{array}$ & Good & $\begin{array}{l}\text {-The speaker has quite good self confidence } \\
\text {-Sometimes stands up straight and establish eye contact } \\
\text {-Sometimes mumbles but can not be understood } \\
\text {-There are mispronounces three until five words } \\
\text {-There are some hesitation during speaking. }\end{array}$ \\
\hline 3 & $\begin{array}{l}\text { AMA } \\
\text { (Introvert) }\end{array}$ & Poor & $\begin{array}{l}\text {-The speaker looks very nervous } \\
\text {-Slouches and/or does not look at people during the } \\
\text { performance } \\
\text {-Often mumbles or can not be understood } \\
\text {-There are a lot of mispronounces } \\
\text {-The contestant does not speak fluently English. There are a } \\
\text { lot of hesitation during speaking. }\end{array}$ \\
\hline 4 & $\begin{array}{l}\text { J } \\
\text { (Extrovert) }\end{array}$ & Good & $\begin{array}{l}\text { The speaker has quite good self confidence } \\
\text {-Sometimes stands up straight and establish eye contact } \\
\text {-Sometimes mumbles but can not be understood } \\
\text {-There are mispronounces three until five words } \\
\text {-There are some hesitation during speaking. }\end{array}$ \\
\hline
\end{tabular}

The Students' Extrovert and Introvert Personality toward Speaking Performance

Novita Paradillah, Muhammad Zuhri Dj., \& Uswatun Hasanah, Page 38-50 
IJRETAL

International Journal of Research on English Teaching and Applied Linguistics, Vol. 1, No.1, June 2020

\begin{tabular}{|c|c|c|c|}
\hline 5 & $\begin{array}{l}\mathrm{AE} \\
\text { (Introvert) }\end{array}$ & Good & $\begin{array}{l}\text {-The speaker has quite good self confidence } \\
\text {-Sometimes stands up straight and establish eye contact } \\
\text {-Sometimes mumbles but can not be understood } \\
\text {-There are mispronounces three until five words } \\
\text {-There are some hesitation during speaking. }\end{array}$ \\
\hline 6 & $\begin{array}{l}\text { IR } \\
\text { (Extrovert) }\end{array}$ & Good & $\begin{array}{l}\text {-The speaker has quite good self confidence } \\
\text {-Sometimes stands up straight and establish eye contact } \\
\text {-Sometimes mumbles but can not be understood } \\
\text {-There are mispronounces three until five words } \\
\text {-There are some hesitation during speaking. }\end{array}$ \\
\hline 7 & $\begin{array}{l}\text { AMT } \\
\text { (Introvert) }\end{array}$ & Good & $\begin{array}{l}\text { The speaker has quite good self confidence } \\
\text {-Sometimes stands up straight and establish eye contact } \\
\text {-Sometimes mumbles but can not be understood } \\
\text {-There are mispronounces three until five words } \\
\text {-There are some hesitation during speaking. }\end{array}$ \\
\hline 8 & $\begin{array}{l}\text { MF } \\
\text { (Extrovert) }\end{array}$ & Poor & $\begin{array}{l}\text { - The speaker looks very nervous } \\
\text {-Slouches and/or does not look at people during the } \\
\text { performance } \\
\text {-Often mumbles or can not be understood } \\
\text {-There are a lot of mispronounces } \\
\text { - The contestant does not speak fluently English. There are a } \\
\text { lot of hesitation during speaking. }\end{array}$ \\
\hline 9 & $\begin{array}{l}\text { I } \\
\text { (Introvert) }\end{array}$ & Poor & $\begin{array}{l}\text { - The speaker looks very nervous } \\
\text {-Slouches and/or does not look at people during the } \\
\text { performance } \\
\text {-Often mumbles or can not be understood } \\
\text {-There are a lot of mispronounces } \\
\text { - The contestant does not speak fluently English. There are a } \\
\text { lot of hesitation during speaking. }\end{array}$ \\
\hline 10 & $\begin{array}{l}\text { MY } \\
\text { (Extrovert) }\end{array}$ & Poor & $\begin{array}{l}\text {-The speaker looks very nervous } \\
\text {-Slouches and/or does not look at people during the } \\
\text { performance } \\
\text {-Often mumbles or can not be understood } \\
\text {-There are a lot of mispronounces } \\
\text {-The contestant does not speak fluently English. There are a } \\
\text { lot of hesitation during speaking. }\end{array}$ \\
\hline
\end{tabular}

Based on the table above that consisted of five introverts and five extrovert students showed that among five extroverts, three students had got "good" and two students got "poor" speaking performance scoring.

It showed that the extrovert students dominantly got the same difficulties such as mumbles, mispronouncing, and some hesitations. It can be said that extrovert students were enough good in self-confidence and eye contact \& gesture criteria where these things relate to extrovert characteristics. While in Introvert students, two students have got "good" and "poor" scoring. The data showed that introvert difficulties dominate the same to an extrovert that was about mumbles, mispronunciation, and some hesitations. The introvert group also found one student who has got "very good" speaking performance scoring. Therefore, it could be said that the characteristics of introvert personality did not determine the success of students speaking.

From the data analysis, the researcher found that there is no influence between personalities both extrovert and introvert in speaking performance. Yan Chen stated that the score of speaking performance and personality type are not correlated (Yan Chen \& Yan, May 
IJRETAL

International Journal of Research on English Teaching and Applied Linguistics, Vol. 1, No.1, June 2020

2015). Therefore, we can say personality types do not influence the outcome of learners' English performance. Based on this research especially the interview processed showed that the factors which influence more by the knowledge and enough time preparation or participation.

\section{DISCUSSION}

Based on the analysis, it can be understood that there are 10 students that consisted of five extroverted and introverted who had been researched based on the instrument above.

1. Dividing extrovert and introvert based on the result of the questionnaire.

Based on the data analysis, among ten students consisted of five extroverts and five introverts who have been decided by using the Eysenck Personality Questionnaire as one of the most well-known and widely used tools for personality measurement in research that was developed by Hans J. Eysenck. The questionnaire is used is It is used to acquire data needed between extrovert and introvert.

2. Analyzing extrovert and introvert based on interview

Among five extrovert students, the result of their speaking test is different, there were three students who had got "good" and two students got "poor" speaking performance scoring. The result showed that the extrovert students dominantly got the same difficulties such as mumbles, mispronunciation, and some hesitations. It can be conveyed that extrovert students were enough good in self-confidence and eye contact \& gesture criteria where these things relate to extrovert characteristics. The reason above, it could be known based on the previous interview, as followed:

a. "Maybe there will not be nervous if I have been mastered the material that will be performed."

b. "I am not too concerned with the mistakes, because in speaking we do not pay attention to much about the grammar."

c. "I am not really afraid of making mistakes, I am just a little bit worried being teased if there is mispronouncing."

d. "For me, it is okay to be seen by my friends, but when we are speaking then our friends pay attention and realized our mistake, I barely would be more nervous."

e. "Seldom to participate, because I do not really understand it."

There are five extrovert students who state that view about speaking performance. It showed that some of them did not really feel afraid and nervous when speaking. It is supported by extrovert characteristics and did not tend to fear making mistakes. While in Introvert students, there were two students who have got "good" and "poor" scoring. The data showed that introvert difficulties dominantly the same as extrovert which was about mumbles, mispronunciation, and some hesitations, the difference is in the introvert group also found one student who has got "very good" speaking performance scoring. The reason above, could be known based on the previous interview, as followed:

a. "It is quite disturbing, but we can ask the teacher or our friend who is able."

$b$. "If the others are focusing on us, we are nervous. Then, if the teacher is also focusing on us we are going to forget our words."

c. "When we are asked to come forward, directly being afraid to be laughed by other friends."

d. "I rarely take a part in speaking. Because I am afraid of making mistakes in front of many people."

e. "For me, is about the way how to pronounce it. I am afraid of mispronouncing."

There are five introvert students who state that view about speaking performance. It showed that some of them have anxiety about making mistakes and it is related by introvert characteristics that are thoughtful, careful, and passive. Analyzing the influence of extrovert and introvert based on speaking test.

3. Analyzing the influence of extrovert and introvert based on speaking test

The Students' Extrovert and Introvert Personality toward Speaking Performance

Novita Paradillah, Muhammad Zuhri Dj., \& Uswatun Hasanah, Page 38-50 
IJRETAL

International Journal of Research on English Teaching and Applied Linguistics, Vol. 1, No.1, June 2020

This speaking test purposed to analyze the influence between both personalities in speaking performance and the result showed that there is no influence between extrovert and introvert personality toward the speaking performance. It is supported by the theory in the previous chapter such as the statement about a few of the introvert students turned out to have better pronunciation and more fluent than the extrovert students for conveying ideas accurately and naturally in speaking (Dorney, 2015). It is caused by the essential of the introvert is an adequate important to assist thought and analysis of others; they are deeply thoughtful and prone to be exceptionally intelligent (Mathilde Almlund).

It is proved by among five extroverts there were three students who were good and two of them were poor. While introvert, there were two students who were good and two of them were poor, but there was one introvert who got very good. It means that whether extrovert or introvert the person is as long as there is support from enough knowledge and frequent participation or preparation well.

Finally, successfully speaking performance was not influenced by extrovert and introvert because every person has their own chance and way in learning but it is caused by different levels of knowledge also frequently participation or preparation well based on the theory on the before. The more knowledge or preparation of the student has, the better performance of the student will be.

\section{CONCLUSION}

Personality is a combination of characteristics that form an individual's character. In this research, there are two types that are discussed, there are extrovert and introvert. Both of them especially in speaking performance. As is known in speaking, extrovert learners are more likely to engage in oral participation than the introverts as students with quiet and passive that make extrovert tents have a good performance but the fact is introvert is a type of person who is thoughtful or person who thinks before deciding something to say orally who is supported the introvert will have a good performance too. Based on the result of the speaking test, successfully speaking performance was not influenced by extrovert and introvert personality because two of them have their own way of learning, therefore both of them have a chance to be better in speaking. Consequently, whether extrovert or introvert as long as the student had enough knowledge about the topic and also was supported by frequent participation or preparation well, the speaking performance would be better. As a result of the study shows that personality types are not a decisive factor for the successes of oral English learning, it can be suggested that students with different personality types may employ different kinds of strategies for learning.

\section{REFERENCES}

Agras, W. Stewart. (2017). The Oxford Handbook of Eating Disorders: Oxford University Press, 15.

Ali Sukru Ozbay, et al, (2017) Extroversion - Introversion in the Context of Foreign Language Learning, Educational Research Association The International Journal of Educational Researchers, vol. 8, No.3, p. 14.

Andila Misti. (2018). The Correlation between Students' Speaking Anxiety and Their Speaking Performance at The Junior High School 3 Tambang,studies in English language and educationUniversitas Islam Negeri Sultan Syarif Kasim Riau, Indonesia.

The Students' Extrovert and Introvert Personality toward Speaking Performance

Novita Paradillah, Muhammad Zuhri Dj., \& Uswatun Hasanah, Page 38-50 
IJRETAL

International Journal of Research on English Teaching and Applied Linguistics, Vol. 1, No.1, June 2020

Arie Lestari, et al. (2015.) Analysis on The Relationship of Extrovert-Introvert Personality and Students" Speaking Performance, Jurnal of teacher training and education english study program,

Clarry Sada, et al. (2015) Analysis on The Relationship of Extrovert-Introvert Personality and Students Speaking Performance, Journal of teacher training and education English study program, vol. 4, No. 3, , p. 1.

Dorney, Z. (2015) The Psychology of the Language Learner: Individual differences in second language acquisition. p. 27.

Dyah Sri Wulandari, (2017). Educational Research: Extrovert And Introvert Students In Speaking Ability Of English Department At IAIN Palangka Raya, P.46.

Fatma Hsain Ali Suliman, (February 2015). The Role of Extrovert and Introvert Personality in Second Language Acquisition, Journal of Humanities And Social Science (IOSR-JHSS), Volume 20, No. 5, p. 109.

Gary R. VandenBos and Jason M.Winkler, (2015),An Analysis of the Status of Journals and Research in Psychology from Latin America, American Psychological Association, Washington, United States, Vol.5, No. 28, p.82.

Hilda Nazlia, (May 2015) "the students' speaking performances between extrovert and introvert and introvert in IAIN Langsa", Journal of Language Teaching and Research, Vol. 6, No. 3, p. 581-587.

Howard S. Friedman and Mirriam W. Schustack, (2008). Personality: Clasic dan Riset Modern Theory, third edition, (Jakarta: Erlangga), p. 134.

Keith F. Punch, Introduction to Research Methods in Education (Singapore: SAGE, 2009), p. 174-175.

L.R. Gay, et al., (2012). Educational Research: Competencies for Analysis and Applications, Tenth Edition, (New Jersey: Pearson Education Inc), p. 443.

Lai-Mei Leong and Seyedeh Masoumeh Ahmadi, (2017). "An Analysis of Factors Influencing Learners' English Speaking Skill”, International Journal of Research in English Education, vol. 3, p. 34.

Lester D. Crow and Alice Crow 1958, Educational Psychology, New York: American Book Company, Revised Edition, p. 4.

Lynne Cohen et al,. (2013). Psychology: An International Discipline in Context: Australian \& New Zealand, Journal of Consulting and Clinical Psychology, p.90.

Marzieh Souzandehfar,( January 10th 2017). Which Personality Trait Performs better on IELTS Speaking Test? Extroverted or Introverted?, Yasouj, Iran: Islamic Azad University, AENSI Journals, online,

Mathilde Almlund, Personality and Personality Traits: Definitions and a Brief History of Personality Psycholog, Personality Psychology and Economics Book(London : Applied Science Publisher LTD, 1972) p. 258.

Merle J. Schwartz, (2007), Effective Character Education: A Guidebook for future Educators, (New York:McGraw Hill). p.5.

Nasution, Metode Research (Bandung: Jemmars, 1987), The second edition.

The Students' Extrovert and Introvert Personality toward Speaking Performance

Novita Paradillah, Muhammad Zuhri Dj., \& Uswatun Hasanah, Page 38-50 
IJRETAL

International Journal of Research on English Teaching and Applied Linguistics, Vol. 1, No.1, June 2020

Nguyen Hoang Tuan and Tran Ngoc Mai, (2015). Factors affecting student's Speaking Performance at LE THANH HIEN HIGH School, Asian Journal of Educational Research.

Nunan, David, (2003), Practical English Language Teaching International Edition $1^{\text {st }}$ Edition Singapore:McGraw-Hill, Educational Research Association The Inter International Journal of Research in Teacher Education, p.48.

Nunan, Guralnik, Language Teaching Methodology a Textbook for Teachers, (NY: Phoenix Ltd., 1995), p. 39.

Oxford Learner's Pocket Dictionary, (2008). The Fourth Edition(Oxford University press,).

Per Bech, et al,. (2012). Eysenck's Two Big Personality Factors and Their Relationship to Depression in Patient with Chronic Idiopatic Pain Disorder: A Clinimetric Validation Analysis, International Scholarly Research Network, Vol. 2, No.1, p.9.

Priyanka Sharma, A Correlational Of Personality Types And Performance Of The Teacher Trainers In The Teacher Training Programme, p.1665.

Sheedy DEE C, (2017). Myers-Briggs Indicator (MBTI) Personality and General Weighted Average (GWA) of Nursing Students: An Introductory of Workbook, (Australia: Gred Stabler AEE,), p. 192

Shiv Prakash et al., (March 2016,) .Personality (Introvert, And Extrovert) and Professional Commitment Effect among B.Ed Teacher Educator Students, The International Journal of Indian Psychology, Volume 3, No. 3, p. 44.

Sri Muniarty Samand, (2019). "Analysis On The Relationship Of Extrovert-Introvert Personality And Students' Speaking Performance In English Study Program Of Halu Oleo University" Journal ofLanguage Education and Educational Technology, Vol. 4, No. 1, p. 2.

W. Stewart Agras, (21 December2017,). The Oxford Handbook of Eating Disorders: Oxford University Press, p. 455.

Sumadi Suryabrata, (2008). Psychology of Personality, (Jakarta: Raja GrafindoPersada,), p.162.

Ur, Penny. (April 23, 2012). A course in Language Teaching. Practice and Theory. Cambridge: Cambridge University Press; $2^{\text {nd }}$ Edition, p. 312.

Wesley Kipsang Bettlet al, (2013). Role of teacher motivation on student's examination performance at secondary school level in kenya (a case study of kericho district),International Journal of Advanced Research.

Yan Chen, et al., (May 2015). A Survey Study: The Correlation between Introversion/Extroversion and Oral English Learning Outcome, Journal of Language Teaching and Research, Vol. 6, No. 3 , p. 584.

Yuen Chee Keong, et al,. (December 2015). Improving Iraqi Secondary Students' Speaking Performance through ProblemBased Learning Approach, International Journal of Education and Research, Vol. 3 No. 12, p. 87. 